\title{
Migration and Climate Change Impacts on Rural Entrepreneurs in Nigeria: A Gender Perspective
}

\author{
Catherine Abiola O. Akinbami
}

check for updates

Citation: Akinbami, C.A.O

Migration and Climate Change Impacts on Rural Entrepreneurs in Nigeria: A Gender Perspective. Sustainability 2021, 13, 8882. https:// doi.org/10.3390/su13168882

Academic Editors: Nasir Mahmood and Irfan Ahmad Baig

Received: 9 June 2021

Accepted: 4 August 2021

Published: 9 August 2021

Publisher's Note: MDPI stays neutral with regard to jurisdictional claims in published maps and institutional affiliations.

Copyright: (C) 2021 by the author. Licensee MDPI, Basel, Switzerland. This article is an open access article distributed under the terms and conditions of the Creative Commons Attribution (CC BY) license (https:/ / creativecommons.org/licenses/by/ $4.0 /)$.
Institute for Entrepreneurship \& Development Studies, Obafemi Awolowo University, Ile Ife 220282, Nigeria; caoakin@oauife.edu.ng or abiolaakinbami1@gmail.com; Tel.: +234-803-344-9681

\begin{abstract}
Although the effects of climate change are universal, some groups are more negatively affected than others, which has raised global concerns. The most affected are families involved with agriculture or that use natural resources in rural areas as a means of livelihood. This study aimed to assess the responses of rural dwellers to climate change and migration, determine the extent of climate change as a driver of migration, assess the viability of migration as an option for climate change adaptation, and evaluate the gender perspective of migration and the impact of climate change on entrepreneurial development in rural areas. A qualitative method was employed to solicit responses from respondents in selected rural areas under four different vegetation zones through in-depth interviews and focus group discussions. Data were analyzed using Atlas.ti. A difference was found in gender reactions to migration due to socio-cultural factors and family responsibilities. In addition, different types of migration patterns were found to exist among men and women. The study also revealed that climate change is a major driver of migration, affects livelihood practices differently in the vegetation zones, and has a negative impact on the entrepreneurship development of the rural areas. Finally, this study provides insights into the effect of migration type on the entrepreneurship development by gender.
\end{abstract}

Keywords: migration; rural women; livelihood practices; gender; entrepreneurship development; climate change

\section{Introduction}

Migration patterns of communities are expected to experience significant changes due to climate change. This is due to increases in the frequency of severe environmental hazards and the sudden onset of disasters. Although the effects of climate change are universal, some areas of human life and groups of people are more negatively affected than others [1]. Migration is unavoidable due to various reasons. The desire to increase economic welfare motivates migrants to move to other communities. According to United Nations High Commission for Refugees (UNHCR) [2], at the end of 2019, 79.5 million people have been forcefully displaced globally, with Africa hosting about $36 \%$ of these. The focus of migration is mainly on urban areas, whereas rural areas are often neglected. Furthermore, rather than on natural disasters emphasis of urban migration includes other reasons, such as conflict and security challenges, governance and regulation, inequalities and uneven development, demographic push, and talent patterns [3]. According to Rodrigue [4], urban areas continue to be plagued with outdated infrastructure and patterns of mobility, and a lack of adequate information regarding the contributions of immigrants to host communities. As a result, immigrants react to the demands of the situation, rather than planning for the future. Additionally, some studies have revealed different impacts and outcomes of migration on communities due to different policies and existing social contexts [5-7]. Due to these reasons, in addition to the related effects, such as poverty and scarcity of resources, it is difficult to transform the lives and livelihoods of people affected by displacement.

In Africa, the causes of displacement are manifold and complex, and are more pronounced in rural areas. Climate change, a major reason for migration in rural areas, is 
considered to be a new driver for human migration that can either prevent or enhance the growth of rural entrepreneurship. This displacement of people is a result of various factors, such as adaptation to climate change. In addition, government response and actions can inform the kind of movement and the different destinations of migrants as they respond to environmental changes.

In recent years, there has been growth in the literature on climate change and migration from different perspectives. The De Sherbinin et al. [8] investigated the development of migration and risk into different net migration patterns for different ecosystems, and Collyer [9] researched the protection provided for various types of migrants. Piguet et al. [10] examined the effects of environmental changes on human migration and identified groups of reasons for the decision to migrate, namely, social, economic, political, demographic, and environmental. De Hass [11] developed new theoretical approaches and insight into forces that drive migration. Backhaus et al. [12] explored the connection between "climate change and international migration" and showed that changes in climate have a fundamental relation with forced migration, especially among those in agriculture. Overall, there is agreement that people migrate to a "greener pasture"; however, the major and pertinent concerns and questions are: (i) Does every climate-induced migrant contribute to the economic growth of both the leaving and destination communities? (ii) How can migration be presented as an adaptation strategy to climate change to drive rural entrepreneurship development and portray gender perspectives? In most cases, migration is seen and perceived as a threat to human communities. As a result, researchers have provided data on vulnerable and displaced people [13-16] without emphasizing the potential opportunities of climate change and migration. This has led to a shortage of information on how entrepreneurial capability can be a tool for reducing the poverty level associated with climate-change-induced migration, especially in vulnerable rural communities in developing countries. This represents a key gap, which is the focus of this paper.

Although different opinions have been expressed regarding whether migration resulting from climate change would be minor or substantial [16], this paper argues that regardless of the level of climate change and induced migration, it can represent a developmental and sustainable tool in rural areas.

The broad objective of this study is to elicit the perspectives and experiences of rural dwellers concerning migration and climate change issues in relation to their livelihood practices. The specific objectives are to: assess the responses of rural dwellers to climate change and migration, determine the extent of climate change as a driver of migration in rural areas, assess the viability of migration as an option for climate change adaptation, and evaluate the gender perspective of migration regarding the impact of climate change on entrepreneurship development in rural areas.

\subsection{Migration and Climate Change}

Climate change and migration have been issues of concern among scientists for a number of decades, and various arguments have been made asserting that climate change is becoming a major driver of population displacement. It was noted in the early 1990s that "climate change greatly influenced human migration, causing displacement of millions of people who suffered erosion, agricultural disruption, and flooding" [17]. Globally, about 25 million people were forced from their families and livelihoods during the mid1990s, due to severe environmental crises, such as drought, flooding, pollution, and natural disasters [17]. This type of movement can be called a "forced migration", as it is a movement in which elements of coercion exist, such as threats to life and livelihoods. Forced migration is not only caused by environmental "push" factors, such as sea level rise, but also "pull" factors, which can also be environmental, social, and economic.

However, Myers [14] stated that the number of "environmental refugees" has surpassed the total due to "war and political oppression", and the study further revealed that the international environmental refugee population would be 50 million by 2010 . Furthermore, an alarming prediction of " 200 million climate migrants by 2050 " has been 
made, meaning that climate change would displace one in every 45 people around the globe $[18,19]$.

The world is still expected to become hotter, with an average temperature increase between 1.8 and $4{ }^{\circ} \mathrm{C}$ by the 2060s if significant policy changes are not implemented. This may lead to increasingly frequent and severe extreme weather events, such as droughts, storms, and floods [20-22], and general changes in rainfall patterns across the globe. Although some countries such as Bangladesh and India will experience more rains by 2050, the annual rainfall in sub-Saharan Africa will be reduced by 10 percent $[23,24]$. This prediction means that most African countries, particularly rural areas, which constitute the so-called food basket and are dependent on agriculture, will be significantly affected. This also implies that the livelihoods of the rural dwellers will be negatively affected, leading to increases in the rate of poverty and food insecurity, which may result in people migrating to find better conditions [25].

\subsection{Migration and Entrepreneurship}

Migration and entrepreneurship are mechanisms for dealing with climate stress that occurs due to climatic change variations, such as change in rainfall patterns, flooding, and drought. These have negative effects on people's livelihood practices, particularly those in rural areas, who depend mainly on natural resources to earn a living and are involved in agriculture. In such cases, migration is seen as a form of adaptive strategy in response to drought [26-28]. For example, in northern Nigeria, with more evidence of drought and desertification, herdsmen are forced to embark on a north-south migration in response to drought due to a lack of grass and water to feed their cows [26]. Consequently, there is a significant increase in forced migration from rural areas when climate stress is combined with economic stress. The agricultural sector, which is an important means of livelihood in rural areas, is also affected. In some cases, climate change conditions have resulted in low productivity in agricultural activities due to drought in the dry season and flooding in the rainy season, thereby leading to irregular livelihood patterns and low soil quality. As a result, men have been able to diversify their livelihood activities via involvement in outmigration agricultural activities and manual work [29-33]. Traditionally, males are more involved in migration, in search of more favorable conditions to increase family income, which has declined because livelihood practices are affected by climate change, thus leaving the women to care for the family [34]. This reveals the gender issues in migration.

According to Momodu et al. [35], the gender perspective relates to the different reactions of men and women to issues in accordance to their socio-economic status, age, and culture. In essence, due to increasing vulnerability in rural areas associated with the lack of access to supportive networks, finance, and land, and the effects of climate change, men from households are dispersed and women remain to take care of the families, livestock, and farmlands $[13,36]$. At present, therefore, migration is a major response to the uncertainties of agricultural activities and all livelihood practices in rural areas to reduce the poverty level. However, the rural-rural migration pattern is common among most middle-aged men in rural areas, whereas most youths migrate to urban areas due to a lack of basic and necessary infrastructure in the rural areas [34,37-39]. Rural dwellers migrate to take part in different activities (farm and off-farm) as coping strategies and to increase the income level; some move to other rural areas to continue farming activities, whereas others abandon farming activities to start small businesses or become apprentices in a new occupation. The income generated from migration activities is sent to family members in the rural areas, often with the aim of re-investing in agricultural activities and in off-farm entrepreneurship development [40-42].

\subsection{Theoretical Framework}

Some studies have revealed that it is not possible to formulate a comprehensive theory of migration due to the involvement of various disciplines in the topic [11,16]. 
Consequently, the theory underpinning this study is based on a combination of theories to provide insights and a strong theoretical foundation.

The micro-theory of neoclassical economics states that migrants likely consider "costs and benefits" of migrating to other places [43]. Theoretically, maximum proceeds are expected over time after migration takes place. However, in practice, a skilled migrant increases the chance of employment and expected earnings in the destination location. The theory also takes into consideration the characteristics of individuals that determine opportunities and earnings, in addition to wage differentials, and technological and social situations, which minimize migration costs. Furthermore, the theory postulates that individuals make the decision to migrate, which is contingent on labor market differences. Therefore, the cost of migration involves emotional and social costs of the individual, and the government can consequently influence migration through policies that impact anticipated earnings at home and host locations.

However, a different line of argument exists in the New Economics of migration theory compared to the micro-theory of neoclassical economics. The New Economics theory postulated that the decision regarding migration is not made in isolation by an individual, but is rather a collective household decision to maximize both revenue and employment opportunities, and to minimize risks [44]. The theory further explained that households directly faced migration risks; therefore, the major motivation to migrate is to diversify risks through a household member, and not only to raise income. This theory positions migration within the framework of the family and community levels. Therefore, to reduce the probability of migration, government policies should not neglect poorer households while raising the income of the population.

The decision to combine the theories was also based on the attempt to capture the theoretically important migration determinants in leaving and destination communities with respect to the salient issues of climate change, migration, and entrepreneurship.

Furthermore, the cultural homogeneity that prevails in rural areas emphasizes the household concept of the New Economics migration theory, in which the decision of an individual is not made in isolation of other household members. In addition, the microtheory of neoclassical economics acknowledges that migration is a concept that comprises many individual decisions of rational actors, and places emphasis on the skills of the household migrant that will enhance maximum cost-benefit estimates from the leaving zone to the receiving destination. Hence, there is a need to combine the two theories to gain a deeper understanding of how migration can be an instrument for rural entrepreneurship growth and development, and for the alleviation of poverty.

\section{Materials and Methods}

This study employed a qualitative method to solicit responses from men and women in selected rural areas under four different vegetation zones in Southwest Nigeria through in-depth interviews (IDIs) and focus group discussions (FGDs) in various communities.

This study looked at food processing, non-farming activities, farming, and non-timber forest products. Results from both in-depth interviews and FGDs were analyzed and combined to address the research objectives, and reveal the gender perspectives in respondents' experiences of the impact of climate change on the migration decision to enhance rural entrepreneurship development.

\subsection{The Study Area}

This study purposively selected Oyo, Ondo, and Ogun States in Southwest Nigeria and represented all of the vegetation zones in the southwest. Three types of vegetation zones are present in Ondo State: mangrove, rainforest, and freshwater swamp. Oyo state possesses rainforest and guinea savanna. Ogun state has the same zones as Oyo, with the addition of freshwater swamp.

The study purposively chose two Local Government Areas (LGAs) with different vegetation zones from each state (see Table 1). One community from each LGA was selected. 
In Oyo State, Araromi Idowu community in Iddo LGA and Aba Serafu community in Iseyin LGA were selected. These represent rainforest and guinea savanna vegetation zones, respectively. In Ogun State, Oke Ola and J4 communities in Imeko Afon and Ijebu East LGAs, respectively, were chosen. These represent woodland savanna and rainforest vegetation zones, respectively. Ondo State, characterized by freshwater swamp and mangrove vegetation zones, and situated in Ajagba community in Ode Irele LGA, and Igbekebo community in Ese Odo LGA were selected. Figure 1a-c shows the study area maps.

Table 1. Survey target.

\begin{tabular}{cccc}
\hline \multirow{2}{*}{ State } & LGA & Community & Vegetation Zone \\
\hline \multirow{2}{*}{ Oyo } & Iddo & Araromi Idowu & Rain Forest \\
\cline { 2 - 4 } & Iseyin & Aba Serafu & Guinea Savannah \\
\hline \multirow{2}{*}{ Ondo } & Ode Irele & Ajagba & Freshwater \\
\cline { 2 - 4 } & Ese Odo & Igbekebo & Mangrove \\
\hline \multirow{2}{*}{ Ogun } & Imeko Afon & Oke Ola & Woodland Savannah \\
\cline { 2 - 4 } & Ijebu East & $\mathrm{J} 4$ & Rain Forest \\
\hline
\end{tabular}

\subsection{Sample Size}

In the communities, each household had at least one person who was involved in food processing, farming, non-farming activities, or non-timber forest products. Research and field workers were able to visit each house within the small communities for sensitization of the research purpose and to solicit their support for participation. However, community leaders assisted in the random selection of men and women, and both migrants and indigenes involved in the different livelihood classifications already identified for FGDs and In-depth interviews

The in-depth interviews only focused on men because the community leaders preferred men. However, the experiences of women were captured during the FGDs, which had more women than men. Six FGDs reflected the four identified business categories and six in-depth interviews were organized in the six chosen communities. A set of FGDs, which comprised 10 rural men and women who were different from the in-depth interview set, was conducted in each community. The total sample size for FGDs was 60 and for the in-depth interviews was 6.

\subsection{Data Analysis}

Gathered data were accurately transcribed into the English language. Atlas.ti was used to analyze data through inductive coding, and different themes were established based on study objectives. Data were coded to attain the saturation level [45]. The results were presented in themes, with the aid of network and content analysis.

\subsection{Ethical Considerations}

The researchers obtained the approval and cooperation of the communities through the community leaders, and the purpose and objectives of the study were well-explained and interpreted for them. Participants were permitted to ask questions concerning the study before consenting to participate in the research. The study was conducted in the participants' preferred language. Participants were assured of the confidentiality of information supplied. 


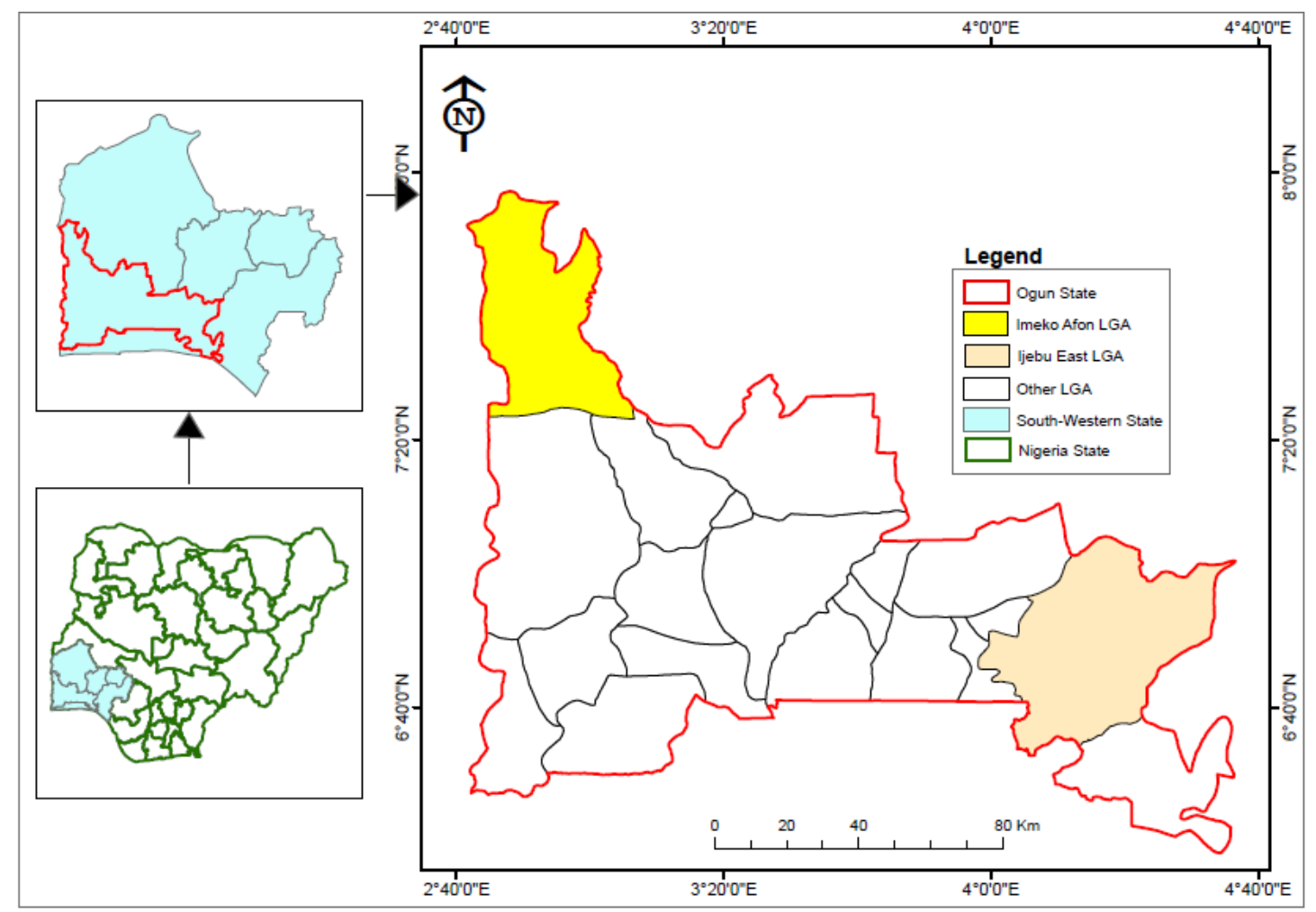

(a)

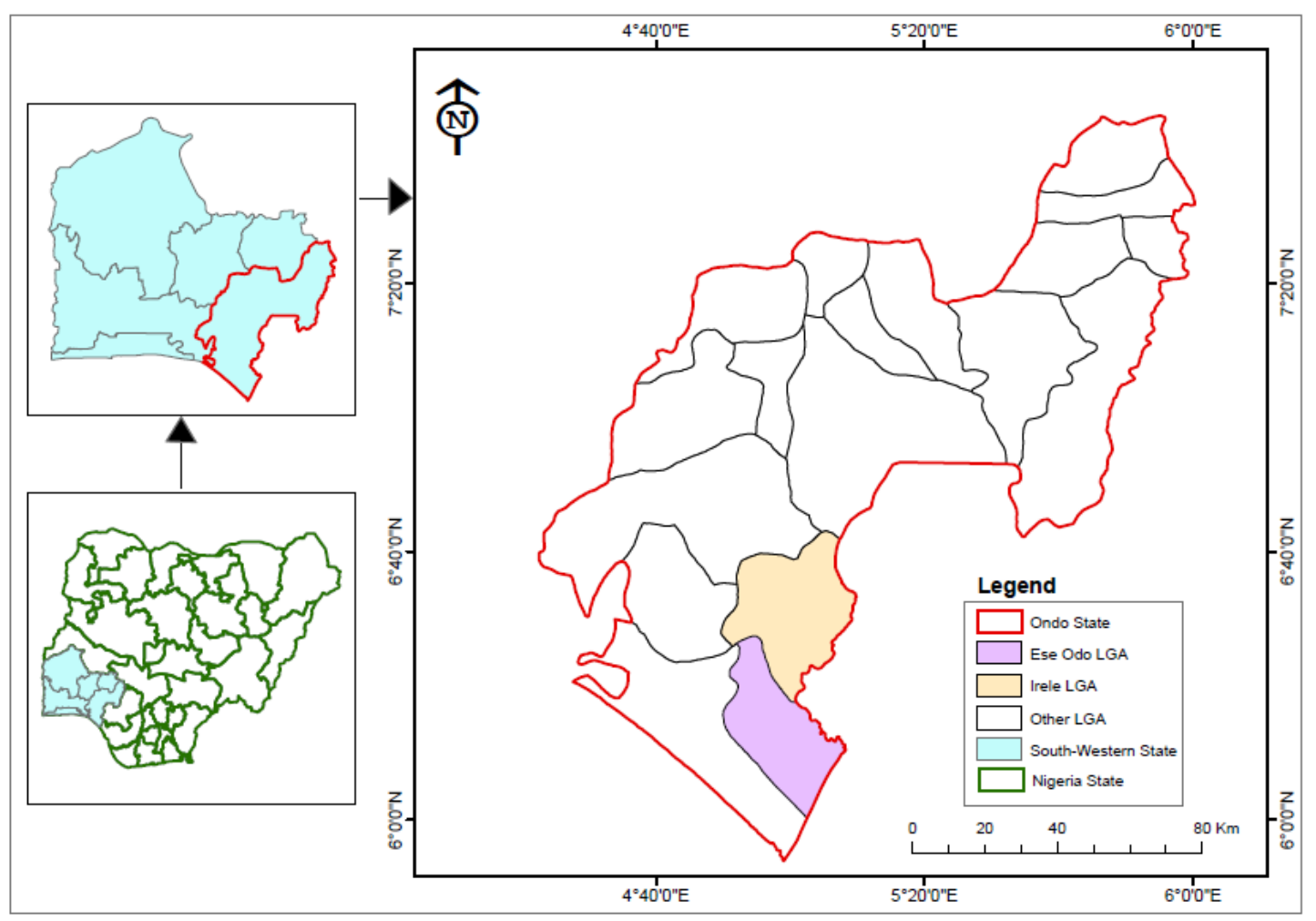

(b)

Figure 1. Cont. 


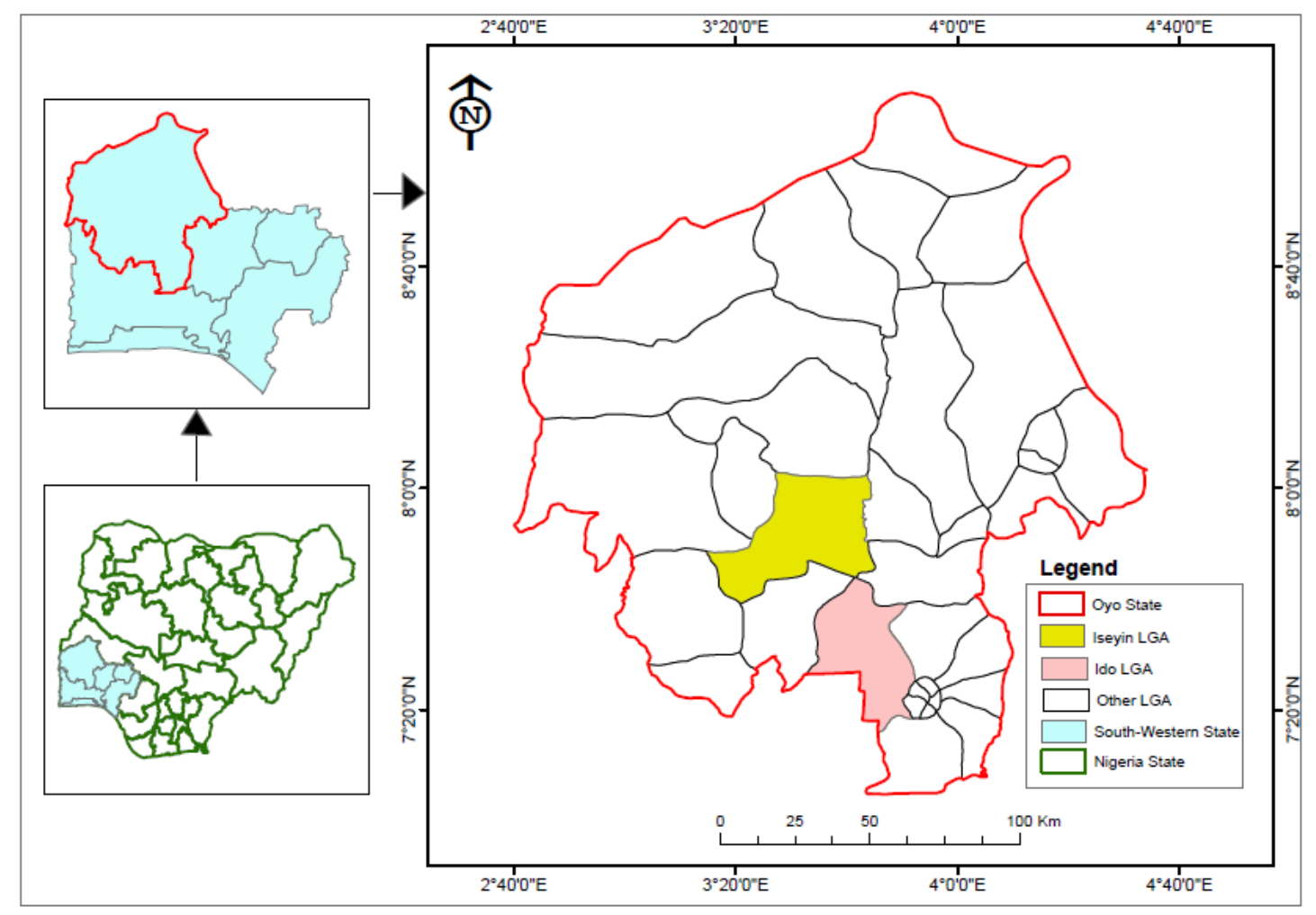

(c)

Figure 1. (a): Ogun State showing Imeko Afon and Ijebu East LGAs; (b): Ondo State showing Irele and Ese Odo LGAs; (c): Oyo State showing Iseyin and Iddo LGAs. Insert of Nigeria States and southwestern States.

\section{Results and Discussion}

Stemming from the acknowledgement of the importance of climate change in migration and its effects on rural entrepreneurs, in addition to identifying gender issues in rural entrepreneurship development, this study aimed to achieve a synergy between climate change and migration to promote entrepreneurship development in the rural areas in Southwest Nigeria, while taking into consideration the gender perspective.

\subsection{Respondent Background Information}

This section presents responses on various background issues relating to climate change and migration as they affect the respondents' livelihood practices. Household information on demographics, farming activities, off-farming activities, migration status, wage patterns, livelihood stressors, and coping strategies were sought. Respondents were told to focus on and discuss the manner in which migration, livelihood practices, and climate change are connected in their communities.

Analyses of the socio-demographic variables of participants for in-depth interviews and FGDs are presented in Tables 2 and 3. Across the vegetation zones, over $70 \%$ of the respondents belonged to the age group between 21 and 55 years old. The respondents' mean age was 45 years, which implies that most of the respondents were in their productive years. This also has consequences for their migration options, particularly among the men and women who are still sufficiently agile to diversify and be involved in more than one livelihood activity. This is essential due to the observation in the communities that about $80 \%$ of the respondents were married and had more than four children to cater for. 
Table 2. Socio-demographic factors of in-depth interview participants.

\begin{tabular}{|c|c|c|c|c|c|c|c|}
\hline & Vegetable Zone & Age & $\begin{array}{c}\text { Educational } \\
\text { Status }\end{array}$ & $\begin{array}{c}\text { Marital } \\
\text { Status }\end{array}$ & Occupation & Religion & Status \\
\hline $\begin{array}{c}\text { Respondent } \\
1 \text {-OYO }\end{array}$ & $\begin{array}{c}\text { Rain } \\
\text { forest-Iddo } \\
\text { LGA }\end{array}$ & 45 years & Primary & Married & Farming & Muslim & Indigene \\
\hline $\begin{array}{c}\text { Respondent } \\
\text { 2-OYO }\end{array}$ & $\begin{array}{c}\text { Savanah-Iseyin } \\
\text { LGA }\end{array}$ & 55 years & $\begin{array}{l}\text { No formal } \\
\text { education }\end{array}$ & Married & Farming & Muslim & Migrant \\
\hline $\begin{array}{c}\text { Respondent } \\
1-\mathrm{ONDO}\end{array}$ & $\begin{array}{c}\text { Mangrove-Irele } \\
\text { LGA }\end{array}$ & 40 years & Primary & Married & Farming & Christianity & Migrant \\
\hline $\begin{array}{l}\text { Respondent } \\
\text { 2-ONDO }\end{array}$ & $\begin{array}{c}\text { Fresh } \\
\text { water-Igde }\end{array}$ & 42 years & $\begin{array}{l}\text { Junior } \\
\text { secondary }\end{array}$ & Married & $\begin{array}{l}\text { Farming/Food } \\
\text { Processing }\end{array}$ & Christianity & Indigene \\
\hline $\begin{array}{c}\text { Respondent } \\
\text { 1-OGUN }\end{array}$ & $\begin{array}{c}\text { Savanah-Imeko } \\
\text { LGA }\end{array}$ & 32 years & Secondary & Married & Farming & Christianity & Indigene \\
\hline $\begin{array}{c}\text { Respondent } \\
\text { 2-OGUN }\end{array}$ & $\begin{array}{c}\text { Rain } \\
\text { Forest-J4/J6 } \\
\text { LGA }\end{array}$ & 45 years & $\begin{array}{l}\text { No formal } \\
\text { education }\end{array}$ & Married & Farming & Muslim & Indigene \\
\hline
\end{tabular}

Source: Survey.

Table 3. Socio-demographic factors of FGD participants.

\begin{tabular}{|c|c|c|c|c|c|c|c|c|c|}
\hline \multicolumn{10}{|c|}{ Focus Group Discussions } \\
\hline & \multirow[t]{2}{*}{ Group Name } & \multirow[t]{2}{*}{ Age Range } & \multirow[t]{2}{*}{$\begin{array}{c}\text { Group } \\
\text { No }\end{array}$} & \multicolumn{2}{|c|}{$\begin{array}{l}\text { Average No of } \\
\text { Children }\end{array}$} & \multicolumn{2}{|c|}{ Sex } & \multicolumn{2}{|c|}{ Status } \\
\hline & & & & $<4$ & $>4$ & Men & Women & Indigene & Migrant \\
\hline $\begin{array}{l}\text { FGD 1-Oyo } \\
\text { State }\end{array}$ & $\begin{array}{l}\text { All Business } \\
\text { categories }\end{array}$ & 20-65 years & 10 & 6 & 4 & 4 & 6 & 8 & 2 \\
\hline $\begin{array}{l}\text { FGD 2-Oyo } \\
\text { State }\end{array}$ & $\begin{array}{l}\text { All Business } \\
\text { categories }\end{array}$ & $22-55$ years & 10 & 8 & 2 & 3 & 7 & 9 & 1 \\
\hline $\begin{array}{l}\text { FGD 1-Ondo } \\
\text { State }\end{array}$ & $\begin{array}{l}\text { All Business } \\
\text { categories }\end{array}$ & 20-70 years & 10 & 4 & 6 & 2 & 8 & 8 & 2 \\
\hline $\begin{array}{l}\text { FGD 2-Ondo } \\
\text { State }\end{array}$ & $\begin{array}{l}\text { All Business } \\
\text { categories }\end{array}$ & 25-65 years & 10 & 5 & 5 & 3 & 7 & 8 & 2 \\
\hline $\begin{array}{c}\text { FGD 1-Ogun } \\
\text { State }\end{array}$ & $\begin{array}{c}\text { All Business } \\
\text { categories }\end{array}$ & 20- 60 years & 10 & 6 & 4 & 4 & 6 & 5 & 5 \\
\hline $\begin{array}{l}\text { FGD2-Ogun } \\
\text { State }\end{array}$ & $\begin{array}{l}\text { All Business } \\
\text { categories }\end{array}$ & 25-60 years & 10 & 5 & 5 & 7 & 3 & 4 & 6 \\
\hline
\end{tabular}

Source: Survey.

The educational status in the communities was also observed to follow the same pattern throughout the study areas. The study revealed that most of the respondents had low or no level of education. This explains why most of the respondents were more engaged in unskilled activities, both at home and the migration destination. About threequarters of the respondents reported the involvement of at least one family member in either "in" or "out" migration activity. However, Imeko LGA, a savanna vegetable zone, experienced more "in" migration than the other zones. This is due to the fact that Imeko LGA shares a boundary with the Republic of Benin, which provides unskilled labor for small land border enterprises.

The study revealed that major activities, such as non-farming, farming, and food processing activities, took place in the different vegetation zones visited, as presented in Table 4 . Across the vegetation zones, it was observed that the involvement of respondents in food processing activity was higher in the savanna zone than other zones. However, respondents reported that the number of people involved in non-timber forest products has fallen. This could be an indication of negative effects of climate change in the study areas. For instance, it was observed by the women that some of the herbal leaves had gone into extinction due to excessive heat. 
Table 4. Major activities of respondents.

\begin{tabular}{|c|c|c|c|}
\hline Business Type & Business Size & $\begin{array}{l}\text { Business Sector } \\
\text { Classification }\end{array}$ & Major Line of Business \\
\hline Farming & Small & Production & $\begin{array}{c}\text { Vegetable Farming, Crop } \\
\text { Farming, Livestock Farming, } \\
\text { Fish Farming }\end{array}$ \\
\hline Food Processing & Small & Production & $\begin{array}{c}\text { Soya Milk Producing, } \\
\text { Garri/Cassava Processing, } \\
\text { Palm oil Processing, Locust } \\
\text { Beans Production }\end{array}$ \\
\hline Food Processing & Medium & Service & $\begin{array}{c}\text { Fish Roasting and Sales, Fufu } \\
\text { Processing }\end{array}$ \\
\hline Non-Farming & Small & Service & $\begin{array}{l}\text { Hair Dressing, Raw Food } \\
\text { Selling, Pharmacy Shop, } \\
\text { Soap Making, Petty Trading, } \\
\text { Cloth Trading, Cooked Food } \\
\text { Selling, Tailoring, Fruit } \\
\text { Selling, Hired Labor. }\end{array}$ \\
\hline $\begin{array}{l}\text { Non-Timber } \\
\text { Forest Product }\end{array}$ & Small & Service & $\begin{array}{c}\text { Snail Picking and Sales, } \\
\text { Mushroom Picking and Sales, } \\
\text { Medicinal Herbs Tendering } \\
\text { and Sales, Firewood picking } \\
\text { Picking and Sales }\end{array}$ \\
\hline
\end{tabular}

\subsection{Connection between Climate Change, Livelihood Practices, and Migration in Rural Communities}

Through the conducted FGDs and interviews, respondents were able to express themselves, and a link was established between climate change and migration as it affects their livelihood practices in relation to gender specificity. Both men and women reported that their various livelihoods had been negatively affected by climate change, due to changes in weather variability to various degrees across the communities, including drought, delayed and irregular rainfall patterns, flooding, and rise in the sea level. These findings are highly pertinent because most livelihood sources in the rural areas, such as agriculture, fisheries, and forestry, are climate-sensitive. This corroborates the results of studies such as those of Akinbami et al. [46] and Nattapon and Dusadee [29], which showed that natural resources and rural environments are already under pressure resulting from climate change impacts.

However, agriculture, which is a major business sector in the rural areas, has been strongly affected by adverse climate change conditions. This is because agricultural activities are extremely prone to the basic climate risks already observed in the study areas, as commonly reported by the respondents:

"The effects of changes in climate are evident in our communities. For instance, we are experiencing more frequent extreme weather events such as increase in temperature, irregular rainfall pattern, drought, sea level rise and floods. All these have affected the development of our economic activities. Therefore, we are poor and marginalized in the country". General expression from respondents across vegetation zones.

Respondents recounted that as a result, their agricultural yields are affected by climaterelated impacts, both in quantity and quality. As temperature has increased, the land has become drier and a withdrawal of water has been experienced, especially by those rural areas in the forest and savanna vegetation zones. As a result, these zones are suffering from increasing water stress. This agrees with previous studies $[46,47]$. Consequently, the changes in rainfall and temperature are impacting their growing seasons, planting, and harvesting calendars, thereby leading to crop failure and loss of livestock.

It was also noted that the sea temperature has increased, thereby leading to a decline in fish farming, which is an important source of income for communities in fresh water vegetation zones. According to respondents who are involved in non-timber activity, drought has 
already caused significant extinction of some plants and trees. By comparison, respondents from the mangrove zone are experiencing more severe storms, and communities in coastal and riverine areas are vulnerable to floods, sea surges, and sea level rise. Figure 2 below shows some of the comments of respondents in the study areas.

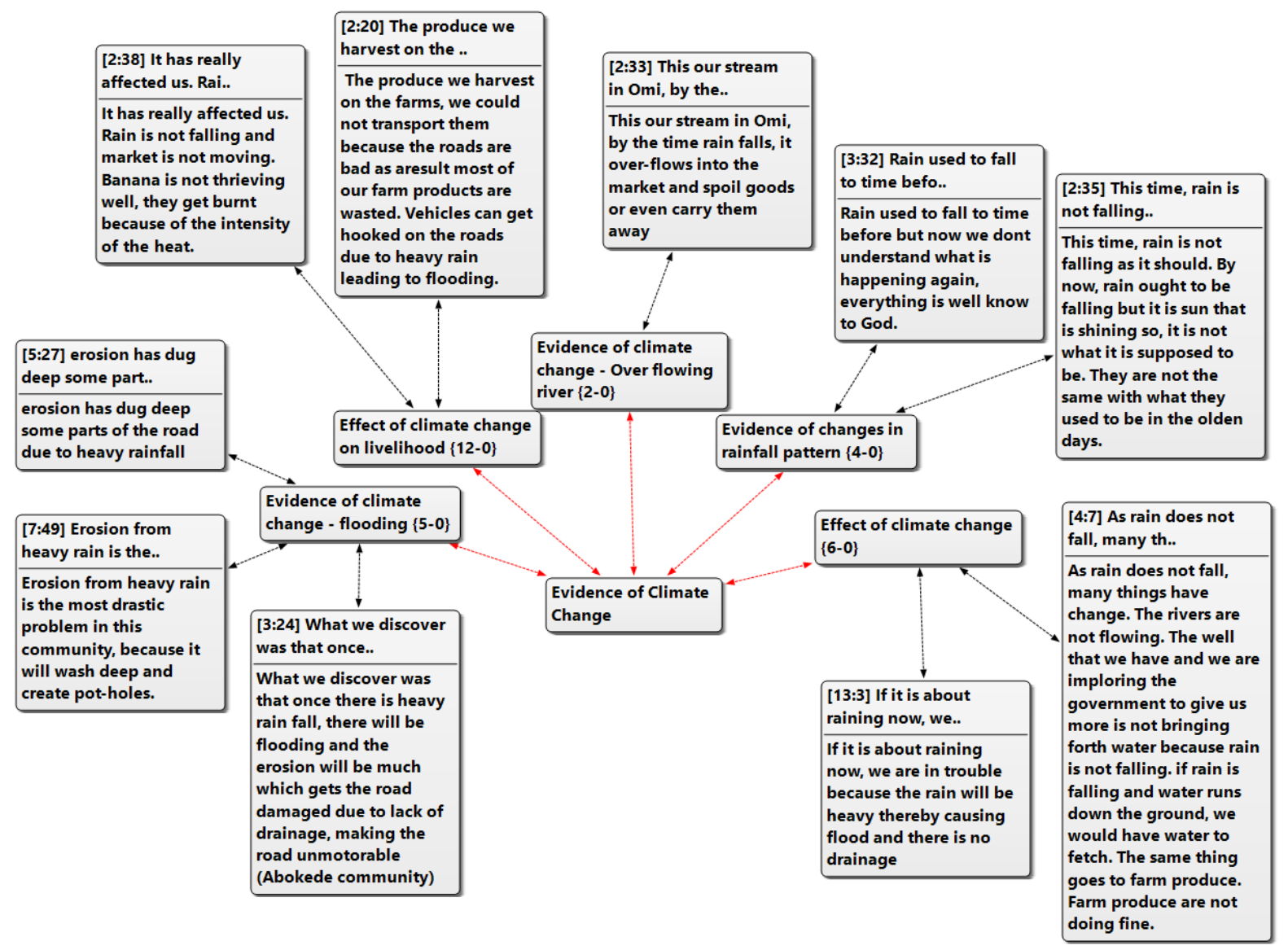

Figure 2. Evidence of Climate Change in the study areas. "Numbers in brackets refer to the interview document and the lines where the quote was drawn from in Atlas.ti, software used for analyze".

It was further gathered that certain factors are responsible for this vulnerability status of the rural areas. Among such factors are lack of weather stations by which rural areas can monitor weather changes and receive useful climate information that can guide the planting season. Another factor is the neglect of the rural areas by the agricultural extension agents, who have to work closely with the residents and provide timely and useful information. The most important factor is the lack of infrastructure and adequate government intervention to help alleviate the severe vulnerability of the rural areas. This lack has exposed more people to food insecurity, hunger, and livelihood insecurity, thereby making rural dwellers seek solutions by migrating as a livelihood strategy to combat poverty. Singh [48] also noted that the decision to move is guided by combinations of goals.

In addition to the effects of climate change on livelihood practices, men's ego, confidence, and dignity were also affected. This is in line with the study of Nelson [49], who stated that in sub-Saharan Africa, small-scale farmers are generally affected by climate change and the impacts are felt differently reflecting gender and social inequalities. Respondents concluded that, due to the effects of climate change on their livelihoods, they considered migration to be a way out, although their preference was to remain in their home environment. This was also affirmed by an earlier study [34]. 


\subsection{Migration Status across Vegetation Zones}

The migration status of community members was sought in the study areas. Respondents reported that nearly every household had a member who had migrated from the communities. For instance, some FGD participants commented:

"In this community, we have come to embrace migration to save ourselves from dying of hunger, since our livelihood practices have been affected by the climate. As a result, more than half of our men have gone out of this village to other places in search of other jobs that can feed us". FGD participant, woman.

"I was into fish farming and processing activity with my parents back home in Ondo State and was also going to school. Due to the effect of the climate change on the livelihood of my parents, l was asked to go and stay with my aunty in the city. On getting there, $l$ got to know that things are easier at the border. That is how 1 got to Imeko, which shares border with Republic of Benin for better livelihood". Youth, out-migrant.

In addition, in-depth interview respondents reported as follows:

"For about 30 years now, even more, our land has not been yielding as before. The rainfall pattern has been erratic, we do not know precisely when to plant our crops again as before and over the years, it has been growing worse. Most of us have diversified, yet the income is still low. We have been managing but now, definite actions must be taken. We had waited even for the government to help, but little or none keeps coming, which we can't depend on. Our children also need to go to school and be better than us and care for the family. Since the cities are better than this community, we have decided to send our younger ones to the city to find their levels for better lives. As a responsible man, you cannot just sit down and watch your family suffering. In order to save our position as heads of the family, we decided to launch out". Indigene, middle-aged man.

"I came to this community in search of better opportunity. I am a farmer from another part of the country. Farming activities had declined in my area because of climate change, but instead of just sitting down to do little or nothing, I decided to join a friend who came to this community last year to work. Though, farming activities here too are not equally doing well but there is an opportunity for people like me in the rural areas. Since most of the men that form the labor force have gone out to the cities, leaving mostly women, aged and children in the rural areas, they need men to help maintain the farm land, which the women cannot do and the farm land cannot be totally abandoned. We still need to produce food in whatever capacity we have, though not much. In this regard, the contract I have in this community is always for a year, but it is renewable". In-migrant.

This study was able to establish that climate change is a major reason for migration in the study areas and affected the livelihood practices of both men and women. Furthermore, it was discovered that the study areas are experiencing two types of migration, which are "in and out" migration. "Out" migration involves men moving away from the study areas to more favorable environments as a result of the impacts of climate change, whereas "in" migration involves men from other communities coming to seize the opportunities associated with the lack of sufficient men to carry out some activities in the study areas. The study established that both "in" and "out" migrants have similar experiences and reasons for migrating.

In the communities visited, it was discovered that youths migrate to urban areas to start another line of business, mainly vocational in nature, which has an adverse effect on the food security of the region. Furthermore, middle-aged men migrate to semi-urban areas to continue their line of business, in addition to another vocation, as a form of diversification to increase income generation. This was found to be common with men involved in food processing and fish farming, who started fish pond and fish processing, and cassava and palm oil processing in semi-urban areas due to greater market access and profitability. In addition, most of those involved in out-migration do not necessarily continue their line of business; they also migrate into other means of livelihoods, such as 
shop assistants or commercial motor cycle riders, whereas those involved in in-migration are mostly involved in farming activities at the migration destination.

Furthermore, the study found that women in rural areas are also involved in a form of migration. Respondents reported during FGDs that some women migrate to semi-urban areas, but only for a short time. This was common among women who do not have small children to cater for and whose husbands have migrated out of the communities. These women remain in the rural areas during planting seasons, but return to their temporary migration destination, and are involved in off-farm activities. In addition to "temporary migration" among women, some also migrate with their husbands, leading to a total change of lifestyle, as reported by the women. However, this option is not practiced by everyone in the rural areas, but only by those who have the resources to relocate. This was also noted by Nelson [49], who found that social, economic, and mental resources are necessary for migration to take place; hence, only those with sufficient resources are able to migrate.

\subsection{Migration Decision Making and Outcomes}

Findings from this study agreed with the established findings of previous studies $[13,19]$ that the decision to migrate is made at the family level. This is consistent with the New Economics theory employed in this study [44].

Respondents reported that migration decisions are normally made after several meetings to decide who will migrate, and when, and the duration, work destination, and type of work to be involved in. However, during these discussions, it was observed that the migrating family member may change the destination if the outcomes do not eventuate as expected. This was reported to be a common practice among the youths. During the FGD at Imeko, due to its proximity to the border, which provides opportunity for more off-farming activities, it was observed that most migrants changed their migration destination to Imeko.

However, some factors guided the decision process, such as familiarity with the host town in terms of culture and geography, and, most importantly, the opportunities for both farm and off-farm activities. According to Thai and Turkina [50], people tend to migrate to towns that have similar belief systems and are closer to the home society. This study found that, in the case of youth migrants, opportunities for off-farm activities take priority when seeking a migration destination. This implies that the strong cultural norms and family ties that still dominate in rural areas may gradually be eroding among the new generation. As a result, farming, which is the major activity in the rural areas, may be neglected, which has significant implications for food security in the country. This may lead to land abandonment and under-development of arable land [51,52]. It was also found that most parents in the rural areas are encouraging their children to migrate into better areas and off-farming activities. This notion was presented with proverbs in the Yoruba language during the FGDs in the study areas:

- "Yoruba language version: Iran meta kii tosi po. FGD participants, women. English version-poverty should not run through three generations".

- "Yoruba language version: iya kii ru iti, ki omo ru isepe. FGD participants, women.

- English language version: a child should not inherit hardship experienced by the mother".

The older generations have seen that there is no future in farming activities as a result of the climate change impacts. According to respondents, this is because the government has no plans for them, and no development is experienced in the rural areas; hence, the rural areas may be neglected.

In most cases, the primary aim of migration is to diversify livelihoods, spread risks to other off-farming enterprises, and generate greater income that can be remitted to family members at home. The aim of this transferred money is to improve the family's welfare and economic status in order to reduce the level of poverty [29,40]. For many visited households, remittances from migrated family members were the main source of income for reinvestment. It was discovered that both temporary and permanent migrants, and in-migrants and out-migrants, are involved in remittal in the communities. However, 
middle-aged men remitted more than youths, both in terms of frequency and quantity. This is clearly due to the family commitment of the middle-aged men. Furthermore, the study revealed that the frequency and amount of remittal differs, as reported by respondents:

"I desired to send money home regularly to care for my children and wife, but I can't because I entered into a yearly agreement. That is, I will only receive my pay at the end of the year, though, he provides accommodation. I only appealed to my boss last year to give me about a quarter of my pay to send to my wife. So, it's my wife that actually takes care of the home front while I am here". In-migrant, in-depth interview.

"In my family, my husband has gone out for greener pasture, he is involved in both off-farming and farming activities. Since our children are still young, I have to stay here in the village to take care of them and the small family business. He sends money to us almost every month. Though, the money is not much, I augment it from my petty business". Indigene, woman, FGD participant.

The above suggests that, regardless of the size or frequency of the remittal, it increases the migrants' social status in the village because, in some cases, new projects were being embarked on, and debts were also paid off. Furthermore, migrants were able to increase their saving capacity.

In the case of the women who practice temporary migration, it was reported that they bring home almost all of the proceeds arising from migration, in contrast to their male counterparts. Consequently, the household structure was observed to have changed from its original cultural family structure because it was found in the communities that women have higher responsibilities, greater autonomy, and greater family administration and burden, as also noted by Rao [53] and Nguyen [33].

\subsection{Is Migration a Viable Option?}

A major question is to determine if migration is really a viable option for the development of rural areas in Southwestern Nigeria. Firstly, it was observed that the benefits of migration depend on the resources and strategies of the people. For instance, the low or non-existent formal education of most intended migrants before leaving the rural areas affects the type of occupation they are involved in at the migration destination. Respondents noted that the unskilled occupations undertaken by youth, in particular, in the host areas include laborers at construction sites, motorcycle riders, and drivers. As a result, the income gained from such unskilled activities will only be enough to meet the basic needs, while major development projects of households and the community are neglected. This study further observed that, in some situations, significant economic gain may not accrue to households and the community. This was evident in the report of respondents that some of the migrants finally returned to the leaving communities when they were physically incapable of working in such menial jobs, thereby increasing livelihood insecurity and the poverty level in the rural areas. This explains the involvement of women in diverse occupations as a means of empowering themselves to cater for household needs, as reported by the women during the FGDs.

The choice and involvement of most migrants in unskilled economic activities is a major contributing factor to the low level of remittances being sent to family members. Hence, due to the high poverty rate prevailing in the rural areas, women are now expecting intervention in the form of adaptation strategies from the government as assistance.

Secondly, their migration intention contributes to the success or failure of migration in the rural areas. The question is whether they are really migrant entrepreneurs who wanted to seize opportunities within and outside their communities? This concern was also raised by Ensign and Robinson [54], who questioned if immigrants can be called entrepreneurs, or if they migrate because they are entrepreneurs. Respondents, both inand out-migrants, stated that the principal reason for migration was to become involved in any economic activity that could earn them money, not necessarily because of business formation. Kloosterman et al. [55] stated that entrepreneurial migration enhances business start-ups and diversification of economic activities; however, the contrary was the case 
in the study areas. As a result, the migrants have not been able to be agents of economic development in their communities, in contrast to the experience in other places [56]. However, this trend was more practiced by the men, both middle-aged and youth, than the women. Most left their homeland without significant entrepreneurial drive or spirit, whereas the women exhibited greater entrepreneurial drive.

It was observed that migration can be an instrument to transform the rural areas if migrants have a proper understanding of entrepreneurship and are adequately skilled.

Entrepreneurship has been identified as a viable tool for the promotion of economic growth and development of rural communities, and this has become necessary in response to the accelerating impacts of climate change on rural livelihood practices in developing countries [45]. Entrepreneurship in this context is seen as a process of identifying an innovative approach to seize opportunities both in leaving and host settlements, and particularly in indigene areas. As this approach is deemed to lead to the development of the rural areas, it will also enhance mobilization of capital, management of skills learnt, and the development of indigenes' initiatives to transform climate change challenges into business concepts and new enterprises. With this knowledge, either at home or in migration destinations, migrants will be prepared to take calculated risks for new and improved products. Consequently, immigrant entrepreneurs can emerge and contribute to the development of both the leaving and host settlements. This economic contribution will help improve their social integration, increase networks, and enhance business success. The link between available opportunities, and the manner in which individuals can identify and seize them, forms a crucial path for successful immigration entrepreneurship to create viable economic activities and development in the rural areas.

\section{Conclusions}

This study showed that climate change has a significant impact on migration patterns in rural areas of Southwest Nigeria.

The study found that there is a difference in gender reactions towards migration as a result of socio-cultural factors and family responsibilities. It was also established that climate change is a major causal agent of migration in the study areas and affects the livelihood practices differently in the four vegetation zones, in addition to having a negative impact on the entrepreneurship development of the rural areas. Despite the impact of climate change on livelihood practices and natural resources in the rural areas, women entrepreneurs do not migrate to the same extent as men and youth. However, some women are involved in temporary migration, whereas most do not migrate but expect intervention in the form of adaptation strategies from the government. Middle-aged men migrate to semi-urban areas. In contrast, youth migrate mostly to urban areas to start another line of business, mainly vocational skills, which has a negative effect on food security of the region. It was discovered that some of the study areas are experiencing two types of migration, namely, "in and out" migration. "Out" migration involves men moving from the study areas for better opportunities elsewhere as a result of climate change impacts, whereas "in" migration involves men from other communities coming to seize the opportunities that arise due to the lack of sufficient men to carry out some activities in the study areas.

For migration to be a viable climate change adaptation option to develop the rural areas, there must be a paradigm shift in the understanding and intention of immigrants to embrace entrepreneurship as a strategy to cope with the effects of climate change. This will enhance the maximum cost-benefit of both leaving and destination communities, and ultimately lead to rural entrepreneurship development and poverty alleviation.

Finally, this study provided an approach for improving the financial base of the rural areas through exposure to entrepreneurship training. Consequently, rural dwellers are equipped to transform challenges posed by climate change into developmental opportunities, and to make informed and appropriate decisions about who, why, and where to migrate. This will consequently produce skilled migrants who will help households in 
both leaving and destination communities to better enjoy the benefits of migration. This vividly highlights the connection between climate change, migration, and entrepreneurship concepts embedded in the theories employed for this study.

Author Contributions: This manuscript is an output from my Post-doctoral research write-up. The Conceptualization, methodology, field work, writing — original draft preparation, and writing were done by me. All authors have read and agreed to the published version of the manuscript.

Funding: "This research was funded by DFID/ACU, UK, under the Climate Impact Research Capacity and Leadership Enhancement (CIRCLE) programme" (grant number 201871) and "The APC was also paid by DIFD/ACU, UK".

Institutional Review Board Statement: Ethical review and approval were waived for this study, due to the following reason: for rural development research, direct and physical consent from the community heads is very vital.

Informed Consent Statement: Informed consent was obtained from all subjects involved in the study.

Conflicts of Interest: The author declares no conflict of interest.

\section{References}

1. IPCC. Summary for Policymakers. In Climate Change 2013: The Physical Science Basis; Contribution of Working Group I to the Fifth Assessment Report of the Intergovernmental Panel on Climate Change; Cambridge University Press: New York, NY, USA, 2013; $1535 \mathrm{p}$.

2. UNHCR. Global Trends Forced Displacement in 2019; UNHCR: Copenhagen, Demark, 2020.

3. Olugbenga, E.O. The Impact of Migration on Internal Security: The Case of Itinerant Fulani Herdsmen in Ekiti State, South West Nigeria. J. Humanit. Soc. Sci. 2013, 16, 77-82.

4. $\quad$ Rodrigue, J.-P. The Geography of Transport Systems, 4th ed.; Routledge: New York, NY, USA, 2020; 456p, ISBN 978-0-367-36463-2.

5. World Economic Forum. Migration and Its Impact on Cities. In Collaboration with PwC October 2017. Available online: http:/ /www3.weforum.org/docs/Migration_Impact_Cities_report_2017_low (accessed on 19 February 2020).

6. International Organization for Migration (IOM). World Migration Report 2018. ISSN 1561-5502, ISBN 978-92-9068-742-9, e-ISBN 978-92-9068-763-4. Available online: https:/ / publications.iom.int/system/files/pdf/wmr_2020 (accessed on 19 February 2020).

7. McAuliffe, M.; Khadria, B. (Eds.) World Migration Report 2020; International Organization for Migration: Geneva, Switzerland, 2019; ISBN 978-92-9068-789-4.

8. De Sherbinin, A.; Levy, M.; Adamo, S.; MacManus, K.; Yetman, G.; Mara, V.; Razafindrazay, L.; Goodrich, B.; Srebotnjak, T.; Aichele, C.; et al. Migration and risk: Net migration in marginal ecosystems and hazardous areas. Environ. Res. Lett. 2012, 7, 045602. [CrossRef]

9. Collyer, M. Stranded Migrants and the Fragmented Journey. J. Refug. Stud. 2010, 23, 273-293. [CrossRef]

10. Piguet, E.; Pécoud, A.; De Guchteneire, P. Migration and Climate Change: An Overview. Refug. Surv. Q. 2011, 30, 1-23. [CrossRef]

11. De Haas, H. The Internal Dynamics of Migration Processes: A Theoretical Inquiry. J. Ethn. Migr. Stud. 2010, 36, 1587-1617. [CrossRef]

12. Backhaus, A.; Martinez-Zarzoso, I.; Muris, C. Do climate variations explain bilateral migration? A gravity model analysis. IZA J. Migr. 2015, 4, 3. [CrossRef]

13. Waddington, C. Livelihood outcomes of migration for poor people. In Development Research Centre on Migration Globalisation and Poverty; Sussex Centre for Migration Research: Sussex, UK, 2003.

14. Myers, N. Environmental refugees: An emergent security issue. In Proceedings of the 13th Meeting of the Organization for Security and Co-operation in Europe (OSCE) Economic Forum, Session III (Environment and Migration), Prague, Czech Republic, 23-27 May 2005.

15. Hartmann, B. Rethinking climate refugees and climate conflict: Rhetoric, reality and the politics of policy discourse. J. Int. Dev. 2010, 22, 233-246. [CrossRef]

16. Black, R.; Adger, W.N.; Arnell, N.W.; Dercon, S.; Geddes, A.; Thomas, D. The effect of environmental change on human migration. Glob. Environ. Chang. 2011, 21, S3-S11. [CrossRef]

17. Lonergan, S. The role of environmental degradation in population displacement. Environ. Chang. Secur. Proj. Rep. 1998, 4, 5-15.

18. Dietz, S.; Stern, N. Note-On the Timing of Greenhouse Gas Emissions Reductions: A Final Rejoinder to the Symposium on "The Economics of Climate Change: The Stern Review and its Critics". Rev. Environ. Econ. Policy 2009, 3, 138-140. [CrossRef]

19. International Organization for Migration. Migration and Climate Change; Series No 31; IOM Migration Research: Geneva, Switzerland, 2008.

20. IPCC. Climate Change: The Physical Science Basis—Summary for Policy Makers; Contribution of Working Group I to the Fourth Assessment Report of the Intergovernmental Panel on Climate Change; Cambridge University Press: Paris, France, 2007 ; p. 10.

21. Burke, E.; Simon, J.B.; Chritidis, N. Modelling the recent evolution of global drought and projections for the twenty-first century with the Hadley Centre climate model. J. Hydrometeorol. 2006, 7, 1113-1125. [CrossRef] 
22. World Bank. Turn Down the Heat-Why a $4{ }^{\circ} \mathrm{C}$ Warmer World Must Be Avoided; The World Bank: Washington, DC, USA, 2012.

23. Houghton, J. Global Warming: The Complete Briefing; Cambridge University Press: Cambridge, MA, USA, 2005; 351p.

24. Nyong, A. Impacts of Climate Change in the Tropics-The African Experience; Avoiding Dangerous Climate Change Symposium; Keynote Presentation; Met Office: London, UK, 2005.

25. IPCC. Climate Change: Working Group II: Climate Change Impacts, Adaptation and Vulnerability (2007b). Available online: http://www.grida.no/climate/ipcc_tar/wg2/561.htm (accessed on 15 April 2007).

26. Aremu, T.; Abraham, P. Herdsmen on the Move: The Burdens of Climate Change and Environmental Migration in Nigeria. In Handbook of Climate Change Resilience; Springer: Berlin/Heidelberg, Germany, 2018; pp. 1-11.

27. Gioli, G.; Khan, T.; Bisht, S.; Scheffran, J. Migration as an Adaptation Strategy and its Gendered Implications: A Case Study from the Upper Indus Basin. Mt. Res. Dev. 2014, 34, 255-265. [CrossRef]

28. Warner, K.; Afifi, T. Where the rain falls: Evidence from 8 countries on how vulnerable households use migration to manage the risk of rainfall variability and food insecurity. Clim. Dev. 2014, 6, 1-17. [CrossRef]

29. Nattapon, M.; Dusadee, A. Factors Influencing Livelihood Security among the Fishing Migrant Households at Places of Origin in Thailand. Int. J. Recent Technol. Eng. 2019, 8, 1573-1579.

30. Iván, M.; Michele, N.; Alessia, B. Effects of Youth Migration on Agricultural Production and Employment in the Rural Areas of Origin in Tunisia. In Proceedings of the 6th Conference of the Italian Association of Agricultural and Applied Economics (AIEAA), Piacenza, Italy, 15-16 June 2017.

31. Chandrasekhar, S.; Mitra, A. Migration, caste and livelihood: Evidence from Indian city-slums. Urban Res. Pr. 2017, 12, 156-172. [CrossRef]

32. Michael, K.; Singh, C.; Deshpande, T.; Bazaz, A. Dimensions of Vulnerability in Rural and Urban Areas: A Case of Migrants in Karnataka. Cape Town: ASSAR Project, University of Cape Town, 2017. Available online: https://goo.gl/cBPi9m (accessed on 15 February 2021).

33. Nguyen, M.T.; Locke, C. Rural-urban migration in Vietnam and China: Gendered householding, production of space and the state. J. Peasant. Stud. 2014, 41, 855-876. [CrossRef]

34. FAO. Rural Migration in Tunisia. In Drivers and Patterns of Rural Youth Migration and Its Impact on Food Security and Rural Livelihoods in Tunisia; Food and Agriculture Organization of the United Nations: Rome, Italy, 2018; 56p, ISBN 978-92-5-130510-2.

35. Momodu, A.S.; Akinbami, C.A.O.; Obisanya, J.F. Achieving Food Security and Climate Change Mitigation through Entrepreneurship Development in Rural Nigeria: Gender perspective. Afr. J. Environ. Sci. Technol. 2011, 5, 834-854.

36. FAO. Evidence on Internal and International Migration Patterns in Selected African Countries. Available online: http://www.fao. org/3/a-i7468e.pdf (accessed on 8 February 2020).

37. Li, L.; Liu, Y.; Wang, X.; Fang, J.; Wang, Q.; Zhang, B.; Xiao, P.; Mohammat, A.; Terwei, A. Different Effects of Regional Spe-cies Pool on Plant Diversity between Forest and Grassland Biomes in Arid Northwest China. PLoS ONE 2015, 10, e0131982. [CrossRef]

38. Kavan, P.S. Informal Sector in Port Moresby and Lae, Papua New Guinea: Activities and Government Response. Int. J. Interdiscip. Soc. Sci. Annu. Rev. 2010, 5, 353-370. [CrossRef]

39. Drissi, M. Tunisia: Breaking the Barriers to Youth Inclusion; World Bank: New York, NY, USA, 2016.

40. Szabo, S.; Adger, W.N.; Matthews, Z. Home is where the money goes: Migration-related urban-rural integration in delta regions. Migr. Dev. 2017, 7, 163-179. [CrossRef]

41. Acosta, P.; Calderón, C.; Fajnzylber, P.; Lopez, H. What is the Impact of International Remittances on Poverty and Inequality in Latin America? World Dev. 2008, 36, 89-114. [CrossRef]

42. Naudé, W.; Siegel, M.; Marchand, K. Migration, entrepreneurship and development: Critical questions. IZA J. Migr. 2017, 6, 5. [CrossRef]

43. Abreu, A. The New Economics of Labor Migration: Beware of Neoclassicals Bearing Gifts. Forum Soc. Econ. 2012, 41, 46-67. [CrossRef]

44. Stark, O.; Bloom, D.E. The New Economics of Labor Migration. Am. Econ. Rev. 1985, 75, 173-178.

45. Friese, S. Qualitative Data Analysis with ATLAS.ti; Sage Publication: London, UK, 2012; 274p.

46. Akinbami, C.A.O.; Olawoye, J.E.; Adesina, F.A.; Nelson, V. Exploring potential climate-related entrepreneurship opportunities and challenges for rural Nigerian women. J. Glob. Entrep. Res. 2019, 9, 19. [CrossRef]

47. Pc, U.; Fn, N. Information Needs for Climate Change Adaptation among Rural Farmers in Owerri West Local Area of Imo State, Nigeria. Agrotechnology 2014, 3, 118. [CrossRef]

48. Singh, C. Migration as a driver of changing household structures: Implications for local livelihoods and adaptation. Migr. Dev. 2019, 8, 301-319. [CrossRef]

49. Nelson, V. Climate Change and Gender: What Role for Agricultural Research among Smallholder Farmers in Africa? CIAT Working Document 2010, No. 222. Available online: https://www.nri.org/images/documents/development-programmes/ climate_change/publications/CIAT_Gender_and_Climate_Change.pdf (accessed on 27 May 2021).

50. Thai, M.; Turkina, E. Entrepreneurial migration: Characteristics, causes and effects. J. Enterprising Communities People Places Glob. Econ. 2013, 7, 188-195. [CrossRef]

51. Adhikari, J.; Hobley, M. Everyone is leaving. Who will sow our fields? The livelihood effects on women of male migration from Khotang and Udaypur Districts, Nepal, to the Gulf countries and Malaysia. Himalaya 2015, 35, 11-23. 
52. Gautam, Y.; Andersen, P. Multiple stressors, food system vulnerability and food insecurity in Humla, Nepal. Reg. Environ. Chang. 2017, 17, 1493-1504. [CrossRef]

53. Rao, N. Migration, mobility and changing power relations: Aspirations and praxis of Bangladeshi migrants. Gender Place Cult. 2013, 21, 872-887. [CrossRef]

54. Ensign, P.C. Robinson, N.P. Entrepreneurs because they are immigrants or immigrants because they are entrepreneurs? A critical examination of the relationship between the newcomers and the establishment. J. Entrep. 2011, 20, 33-53.

55. Kloosterman, R.; Russell, A.; Rath, J. Immigrant Entrepreneurs: Venturing Abroad in the Age of Globalization; Berg Publishers: New York, NY, USA, 2003.

56. Chrysostome, E.; Lin, X. Immigrant entrepreneurship: Scrutinizing a promising type of business venture. Thunderbird Int. Bus. Rev. 2010, 52, 77-82. [CrossRef] 